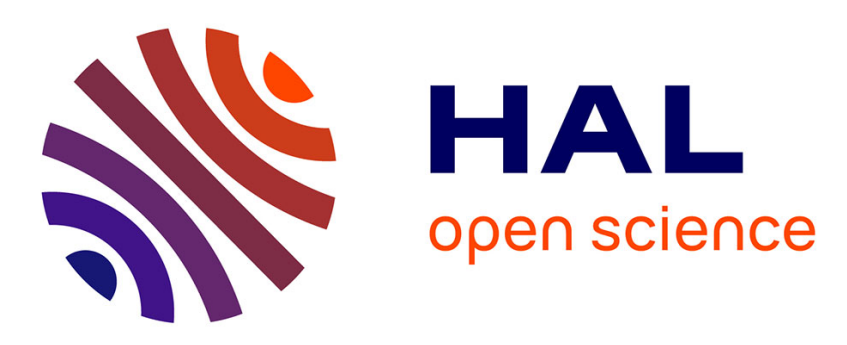

\title{
Climate Change and Risk Perceptions in Two French Coastal Communities
}

Marie-Hélène Ruz, Caroline Rufin-Soler, Arnaud Héquette, Rachel Révillon, Anne-Peggy Hellequin, Philippe Deboudt, Vincent Herbert, Olivier Cohen, Florian Lebreton, Lucie Le Goff, et al.

\section{To cite this version:}

Marie-Hélène Ruz, Caroline Rufin-Soler, Arnaud Héquette, Rachel Révillon, Anne-Peggy Hellequin, et al.. Climate Change and Risk Perceptions in Two French Coastal Communities. Journal of Coastal Research, 95 (1), pp.875-879, 2020, Proceedings from the 16th International Coastal Symposium (Global Coastal Issues of 2020), 10.2112/SI95-170.1 . hal-03085641

\section{HAL Id: hal-03085641 https://hal.science/hal-03085641}

Submitted on 21 Dec 2020

HAL is a multi-disciplinary open access archive for the deposit and dissemination of scientific research documents, whether they are published or not. The documents may come from teaching and research institutions in France or abroad, or from public or private research centers.
L'archive ouverte pluridisciplinaire HAL, est destinée au dépôt et à la diffusion de documents scientifiques de niveau recherche, publiés ou non, émanant des établissements d'enseignement et de recherche français ou étrangers, des laboratoires publics ou privés. 


\title{
Climate Change and Risk Perceptions in Two French Coastal Communities
}

\author{
Marie-Hélène Ruz ${ }^{\dagger *}$, Caroline Rufin-Soler ${ }^{\S}$, Arnaud Héquette ${ }^{\dagger}$, Rachel Révillon ${ }^{\dagger}$, Anne-Peggy Hellequin ${ }^{*}$, \\ Philippe Deboudt ${ }^{\S}$, Vincent Herbert ${ }^{\S}$, Olivier Cohen ${ }^{\dagger}$, Florian Lebreton ${ }^{\S}$, Lucie Le Goff ${ }^{\dagger}$, François G. \\ Schmitt ${ }^{\dagger}$, Denis Marin ${ }^{\dagger}$ \\ $\dagger^{\dagger}$ Laboratoire LOG - UMR CNRS \\ Université du Littoral Côte d'Opale \\ Université de Lille, France \\ $\S_{\text {Laboratoire TVES }}$ \\ Université du Littoral Côte d'Opale \\ Université de Lille, France \\ * Laboratoire LADYSS - UMR CNRS
Université de Paris Nanterre \\ France \\ www.cerf-jcr.org
}

\begin{abstract}
Ruz, M.-H., Rufin-Soler, C., Héquette, A., Révillon, R., Hellequin, A.-P., Deboudt, P., Herbert, V., Cohen, O., Lebreton, F., Le Goff, L., Schmitt, F.G., Marin, D., 2020. Climate change and risk perceptions in two French coastal communities. In: Malvárez, G. and Navas, F. (eds.), Proceedings from the International Coastal Symposium (ICS) 2020 (Seville, Spain). Journal of Coastal Research, Special Issue No. 95, pp. 875-879. Coconut Creek (Florida), ISSN 0749-0208.

Understanding public perception of climate change risks in coastal communities is a prerequisite for effective climate adaptation. This study aimed at evaluating the potential impacts of climate change on two coastal communities on the northern coast of France by producing prospective maps of the coastline by 2065 and at assessing the local inhabitants' risk perception and preferred strategies for facing future coastal risks through a survey of 285 households. The solutions inhabitants considered the more appropriate to preserve their living environment while adapting to the potential impacts of climate change were analyzed. A vast majority of the inhabitants is aware of coastal risks in their municipality, but their feeling of exposure is spatially-influenced depending on the distance to the hazard source. Conversely, no relationship was found between preferred strategies for facing future coastal risks and proximity to the shoreline. In the municipality where only soft defense structures are present, more inhabitants opt for the "hold the line" solution, while in the other municipality where a portion of the coast is protected by a seawall, a much larger proportion of the surveyed residents prefer the adaptation option.
\end{abstract}

ADDITIONAL INDEX WORDS: Climate change, coastal hazards, risk perception, adaptation strategies.

\section{INTRODUCTION}

Climate change will likely have dramatic impacts on coastal communities that will be increasingly affected by coastal erosion and/or marine flooding during the $21^{\text {st }}$ century (Barnard et al., 2019) as a result of sea-level rise and possible changes in wind/wave conditions and storm regimes (Cazenave and Le Cozannet, 2014; Mölter et al., 2016). Population density is already considerably higher in the coastal zone compared to inland areas and the population at risk of marine flooding may increase by several hundred million people in the next decades due to population growth and sea-level rise (Jongman et al., 2012; Neumann et al., 2015). Climate change will therefore result in increasing coastal hazards posing threats to coastal communities that will require appropriate adaptation and/or mitigation strategies.

Public perception of risks can constrain and influence political, social and economic action (Leiserowitz, 2006), and a better understanding of risk perceptions of coastal residents can be a key factor for implementing effective adaptation strategies to coastal hazards and climate change (Button, 2013; Carlton and Jacobson, 2013). Although studies conducted on risk perception of coastal populations generally show that coastal inhabitants

DOI: 10.2112/SI95-170.1 received 31 March 2019; accepted in revision 13 February 2020

*Corresponding author: ruz@univ-littoral.fr

${ }^{\circ}$ Coastal Education and Research Foundation, Inc. 2020 who may be potentially affected by natural coastal hazards (e.g., marine flooding) are often aware of local risks (Elrick-Barr et al., 2015; Kellens et al., 2011; Michel-Guillou and Meur-Férec, 2017), there is limited information on the perception by coastal populations of future coastal hazards that will likely increase with climate change despite a growing interest for these issues during recent years (Mills et al., 2016; Ngo et al., 2019)

This paper presents preliminary results from a research project aimed at (1) assessing the risk perceptions of coastal residents of two coastal communities of northern France threatened by coastal erosion and marine flooding and at (2) evaluating the strategy preferences of the populations to face coastal changes that will likely be caused by climate change in the next 50 years. For both sites, recent coastal evolution raises the problem of vulnerability to coastal erosion and marine flooding that will increase in the next future due to rising sea level and possible higher frequency of extreme events associated with climate change (IPCC, 2013). These two sites were chosen to implement a participative project with local population and stakeholders in order to try to develop solutions of adaptation to climate change. One of the main originality of this project lies in the development of a participatory action research involving scientists from geosciences, oceanography, humanities and social sciences, with local populations to develop coconstruction adaptation strategies to cope with climate change, which will ultimately be shared with coastal managers, state 
stakeholders and decision-makers. This article focuses on the results of a questionnaire survey carried out among the local inhabitants of the two studied municipalities concerning coastal risk perception and preferred strategies for facing future coastal hazards associated with climate change.
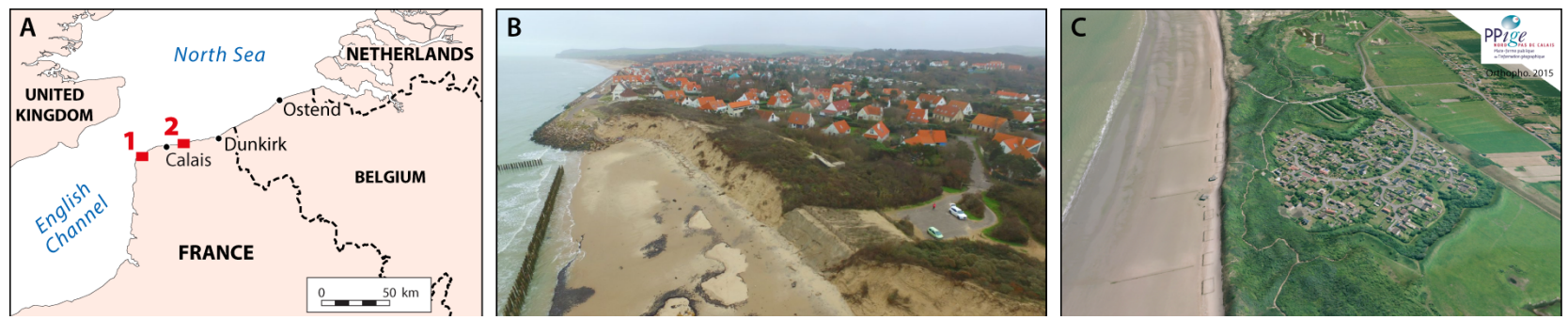

Figure 1. (A) Location of the studied sites : 1: Wissant, 2: Oye-Plage; (B) Photograph of the housing estate threatened by coastal erosion in Wissant (source: Amis de Wissant); (C) Oblique aerial view of the housing estate at Oye-Plage protected from marine flooding by an eroding coastal dune.

\section{Study Area}

This study was conducted at two localities of the coast of northern France where some properties are threatened by coastal erosion or marine flooding. At both sites, coastal dunes, which represent the only defense against the sea for some of the households, have experienced erosion and shoreline retreat during the last decades (Chaverot et al., 2008; Crapoulet et al., 2017). The first site is Wissant, a small coastal resort (981 permanent residents) located on the French coast of the Dover Strait (Fig. 1A). An extensive section of the sea front is protected by a seawall promenade that suffered massive damages on several occasions in recent years, and which is now armored with riprap. In the western part of the village, a real estate development is directly threatened by the erosion of the coastal dune (Fig. 1B) that locally resulted in a shoreline retreat of more than $200 \mathrm{~m}$ during the second half of the $20^{\text {th }}$ century. Coastal erosion continues to occur nowadays, causing dramatic shoreline retreat that may exceed $10 \mathrm{~m}$ during major storms such as the ones that hit Western Europe during the fall-winter 20132014 (Crapoulet et al., 2017).

The second site is Oye-Plage, a village of 5260 inhabitants between Calais and Dunkirk (Fig. 1A). A Nature Reserve called "The Platier d'Oye" has the particularity of hosting a housing estate (les Ecardines) where 153 houses constructed in the mid 70 's are located below the highest tide level (Fig. 1C). This estate is protected from the sea by an eroding sand dune less than $100 \mathrm{~m}$ wide. In the central area of the Platier d'Oye, shoreline retreated by about $50 \mathrm{~m}$ since 1949 . Behind the coastal dunes, the estate is at risk of marine flooding and State Authorities have implemented a plan for coastal safety (Plan de Prévention des Risques Littoraux). This plan imposes to the property owners to build stairs to access the attic and roof windows to enable their rescue in case of flooding.

\section{METHODS}

Several public meetings were organized in 2017-2018 at each survey site for presenting the objectives and the results of the project to the local population. In addition, a door-to-door survey was conducted in the two coastal communities.

\section{Prospective Mapping of Future Coastal Risks and Communication to Population}

Historical shoreline changes since the middle of the $20^{\text {th }}$ century, based on series of orthorectified vertical aerial photographs from 1949 to 2015 , were presented during one of the first meetings for identifying the areas that underwent erosion during the last decades. Prospective maps of the coastal zone in 50 years (relative to 2015), based on documented shoreline evolutions and taking into account future sea level rise were then produced. These maps were based on high-resolution airborne LiDAR topographic data (vertical error $<15 \mathrm{~cm}$ ) obtained in 2016 as baseline topography and on a sea level rise projection of $23 \mathrm{~cm}$ by 2065 corresponding to the RCP6.0 scenario (IPCC, 2013). In addition, the maximum water level during a 100 year return period storm event was calculated, based on tide gauge records from nearby tide stations and on wave data recorded at an offshore wave buoy. The highest rates of shoreline change observed between 1949 and 2015 were selected for projecting the shoreline position in 2065. The generated maps not only show the expected shoreline position in 2065, and corresponding land loss, but also the areas along the coast where marine flooding will likely take place during a significant storm event. These prospective maps were presented to the local population during public meetings in order to raise public awareness concerning the nature and location of coastal hazards that may threaten these coastal communities during the next decades and to incite reactions from the inhabitants for seeking solutions to the foreseen problems. These maps could also be consulted online by the inhabitants through the website of the project (https://cosaco.univ-littoral.fr/). During following meetings, possible technical solutions and strategies for facing these future risks were presented and discussed with the inhabitants.

\section{Survey Data Collection}

After the presentation to the local populations of the prospective maps and possible solutions for coping with future coastal change, the door-to-door survey was conducted in June and July 2018. Because the surveyed municipalities extend several kilometers inland, our investigations were limited to the 
coastal fringe to restrict our survey to the coastal population. Permanent residents as well as second home owners were surveyed. In Wissant the proportion of vacation homes is very significant (67\%) compared to Oye-Plage (10\%).

285 people were interviewed, 162 in Wissant and 123 in OyePlage (Révillon, 2018). The survey consisted of 99 questions covering the following topics: (1) housing, (2) attachment to the land and coastal activities, (3) coastal risks, (4) knowledge of coastal risk and feeling of exposure, (5) memory of past risks and vision of the future, (6) information about coastal risks, and (7) knowledge about coastal protection techniques and strategies. Four possible scenarios were proposed for future shoreline management strategies: (1) "hold the line" (i.e., protect the shoreline by strengthening the defenses against the sea), (2) adapt, depending on individual and collective stakes, (3) relocation (retreat) of activities and goods, or (4) do nothing.

\section{RESULTS}

In both coastal communities, male and female were equally represented. In Wissant, $48.8 \%$ of the respondents were permanent residents and $50.6 \%$ were second home owners, the remaining $0.6 \%$ corresponding to tourists, whereas in Oye-Plage the permanent residents accounted for $89.5 \%$ of the respondents, which is close to the proportion of main residences in this municipality. At Wissant, the lower representativeness of the number of second home owners in our survey compared to the overall proportion of secondary homes could be explained by the absence of some second home owners in July.

A large proportion $(\approx 80 \%)$ of surveyed residents own their houses and the majority of them own their house for more than 20 years (56\% in Wissant, $53 \%$ in Oye-Plage). The respondents over 55 years old are $48.8 \%$ at Oye-Plage and 59.2 $\%$ at Wissant and in both municipalities the retired persons are in large numbers $(30 \%)$. The socio-professional categories and the level of education (thus the level of income) is however very different between the two investigated municipalities. In Wissant, more than $40 \%$ of respondents have high managerial and professional occupations and a high level of education with $46 \%$ of the surveyed residents having a high to very high education level (master's or doctoral degree). In Oye-Plage, intermediate and lower services and technical occupations predominate $(70 \%)$, residents with a high and very high level of education representing only $17 \%$ of the sample.

\section{Perception of Coastal Risks}

A large majority (about $80 \%$ ) of surveyed residents is aware of coastal risks in their municipality. However, when they are asked if their house is exposed or not to coastal erosion and/or to marine flooding, the results are very different (Fig. 2). In OyePlage, $35 \%$ of the residents consider that their house is not threatened by a coastal risk while $64 \%$ believe their house is at risk (Fig. 2B). In Wissant, 59\% of the residents do not think their home is exposed to a coastal risk and $42 \%$ consider that their house is exposed (Fig. 2A). At both sites, the feeling of exposure to coastal risks varies spatially, the majority of the residents who responded that their home is endangered living close to the shoreline. In Wissant, the feeling of exposure to coastal risks is clearly spatially-related, virtually all of the inhabitants of the old village located on a height (mainly permanent residents) are not concerned by coastal risks, while the people living close to the beach (mainly second home owners) are aware that their house can be endangered (Fig. 2A).

When the residents were asked what the major causes of coastal risks are, the first cause identified is climate change, with $28 \%$ of the surveyed residents at Oye-Plage and $25 \%$ at Wissant believing that climate change is the main reason of coastal erosion. A similar result was obtained for marine flooding, climate change being the first response at Oye-Plage (20\%) and at Wissant $(23 \%)$.

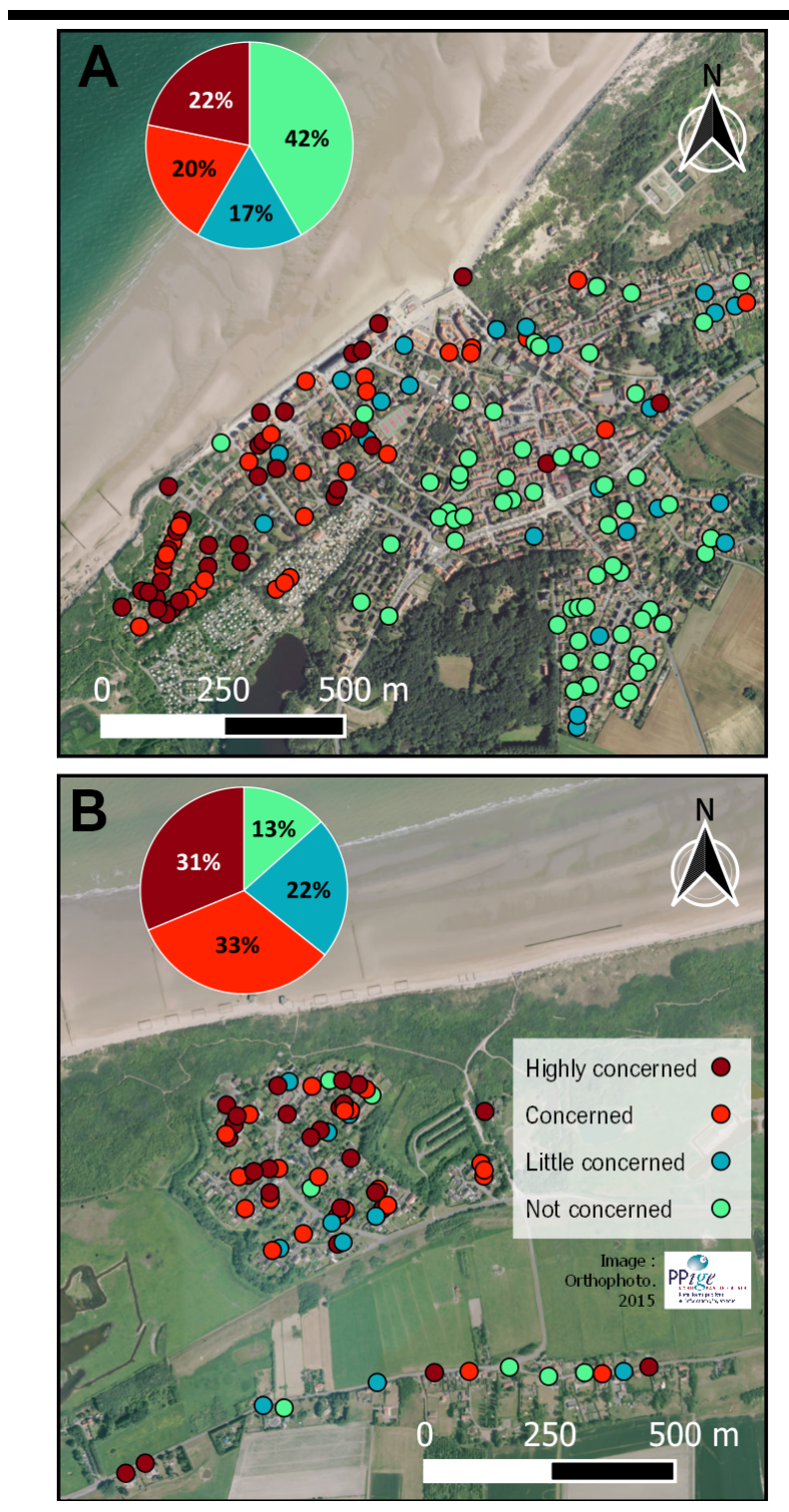

Figure 2. Perception of coastal risks (coastal erosion and/or flooding) by the coastal population of (A) Wissant and (B) Oye-Plage. The pie charts present the results for the total surveyed population in each municipality, while the aerial photographs show only a portion of the surveyed territory, especially for the lower photograph (B) showing mainly the Ecardines housing estate at Oye-Plage. 


\section{Preferred Strategies for Coping with Future Coastal Risks}

The results of the survey show that the preferred strategies for facing future coastal risks are by far adaptation (depending on individual and collective stakes) and protection (hold the line). At Oye-Plage, adaptation and protection strategies are equally preferred with $41 \%$ and $43 \%$ respectively (Fig. 3B), whereas at Wissant, the majority of the surveyed residents prefer adaptation measures (53\%) and $25 \%$ opt for holding the line (Fig. 3A). The third preferred strategy is relocation at both sites while very few inhabitants $(\leq 5 \%)$ consider "do nothing" as a scenario for the future.
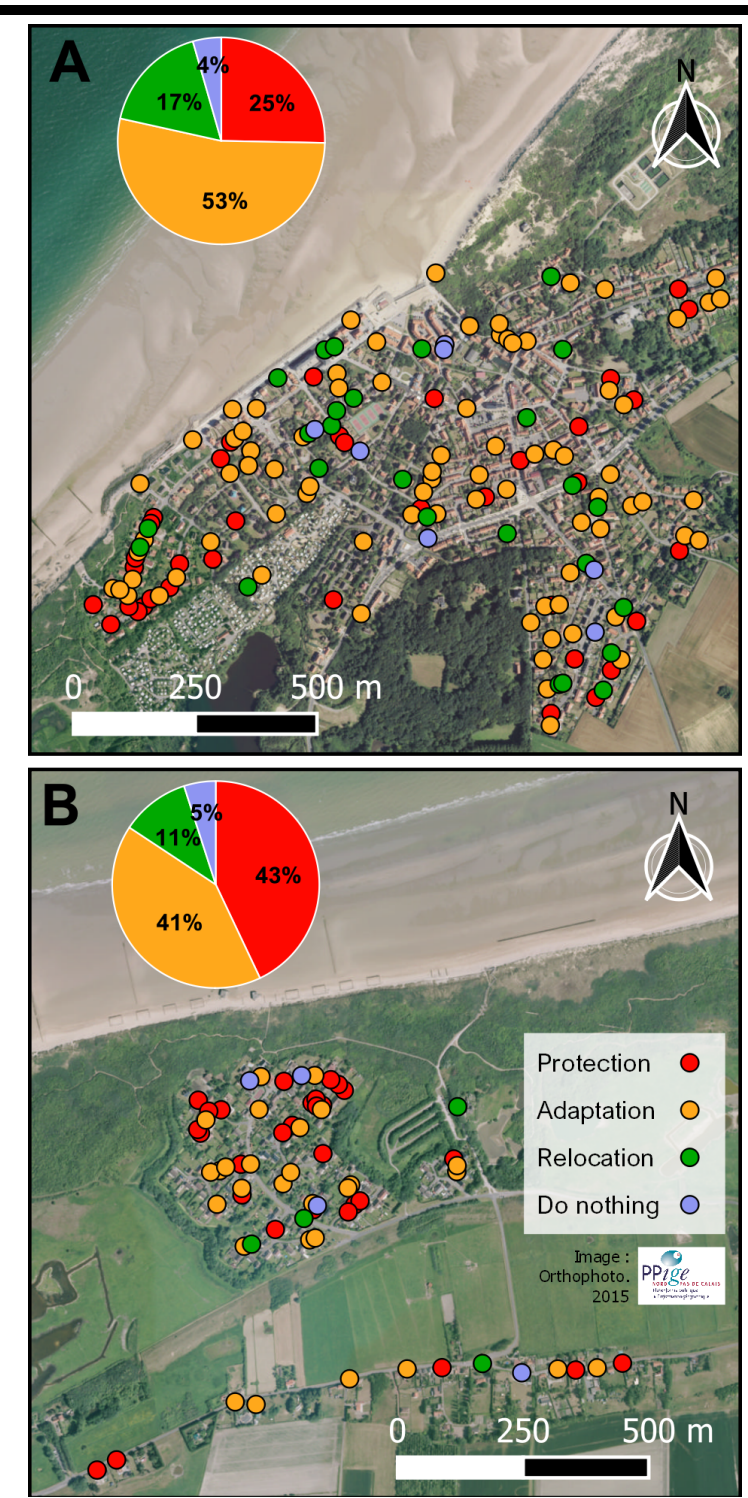

Figure 3. Preferred strategies at (A) Wissant and (B) Oye-Plage for facing future coastal risks associated with climate change. The pie charts present the results for the total surveyed population in each municipality, while the aerial photographs are insets showing a portion of the surveyed territory.
Conversely to what was observed with risk perceptions, the preferred strategies do not appear to be spatially-controlled as some residents living on the seafront at Wissant, for example, opt for the relocation solution while some individuals living far from the sea in the old village are inclined to favor the "hold the line" solution (Fig. 3A).

\section{DISCUSSION}

These results show that in both coastal communities, most of the inhabitants are aware that the littoral strip is exposed to coastal risks. At both study sites, no relationship between education level and perception of risk was found, conversely to what was observed in the Netherland by Botzen et al. (2009) who noticed that more highly educated individuals have a lower flood risk perception in their study of flood risk perception. In the present study, the personal perception of coastal risks by inhabitants is strongly influenced by the location of their house, and notably by the distance to the shoreline. These results are consistent with previous studies that showed that coastal risk perception depends, at least partly, on the distance to the hazard, people leaving farther away from a hazard source generally exhibiting lower levels of perceived risks (Lechowska, 2018; O'Neill et al., 2016).

Concerning the preferred strategies for facing future coastal risks, the proximity to the shoreline is not a determinant factor. A large proportion of inhabitants surveyed in both communities do not consider relocation as an option for responding to climate change (Fig. 3), this result being in line with a number of previous studies showing that retreat is generally rejected by coastal residents (e.g., Douglas et al., 2012). At Oye-Plage, more people $(43 \%)$ want protection at any cost compared to Wissant (25\%). In Wissant, people possibly feel more protected by the presence of a hard coastal defense structure, which is not the case at Oye-Plage where only soft defense structures (wooden groins and sand fences) are present on the upper beach. Furthermore, at Oye-Plage the plan for coastal safety that obliges the property owners to adapt their home in the area at risk of flooding could be an additional reason for preferring the "hold the line" option for a large proportion of the residents.

In both coastal municipalities, the surveyed residents identify climate change as the first cause of coastal risks, showing that a significant proportion of the population is aware of the impacts of climate change. This differs from the findings of Spence et al. (2011) who found no evidence that living in areas vulnerable to climate change influence the perception of risks related to climate change. The high level of awareness of climate change risks in the studied communities may be due to the implementation of a plan for coastal safety in both municipalities, but also to the presentation to the local population of prospective maps of future coastal risks with climate change.

\section{CONCLUSIONS}

One of the conclusion of this study is that a large proportion of the surveyed population living in two coastal municipalities of northern France clearly identify climate change as a major cause of coastal risks, showing that most residents are aware of 
the potential impacts of climate change. The results presented in this paper also highlight that the feeling of exposure to coastal risks in these coastal communities is spatially-influenced, the distance to the hazard source being a major factor of risk perception. Conversely, no relationship was found between preferred strategies for facing future coastal risks and proximity to the shoreline. Preliminary analyses suggest that the level of education may influence preferred strategies. Nevertheless, further analyses of other socio-economic factors are needed for strengthening these first results.

\section{ACKNOWLEDGMENTS}

This work was funded by the Fondation de France through the project COSACO and by the Région Hauts-de-France through the project AD'ACPOP. The authors are grateful to the Mayors of Wissant and Oye-Plage who graciously lent us their communal hall for the public meetings. The inhabitants of Wissant and Oye-Plage are also thanked for their participation to the project.

\section{LITERATURE CITED}

Barnard, P.L., Erikson, L. H., Foxgrover, A.C., Finzi Hart, J.A., Limber, P., O’Neill, A. C., van Ormondt, M., Vitousek, S., Wood, N., Hayden, M.K. and Jones, J.M., 2019. Dynamic flood modeling essential to assess the coastal impacts of climate change. Nature - Scientific Reports, 9: 4309.

Botzen, W. J. W., Aerts, J. C. J. H. and Van Den Bergh, J. C. J. M., 2009. Dependence of flood risk perceptions on socioeconomic and objective risk factors. Water Resources Research, 45(10). W10440, doi:10.1029/2009WR007743.

Button, C., 2013. Coastal vulnerability and climate change in Australia: public risk perceptions and adaptation to climate change in non-metropolitan coastal communities. $\mathrm{PhD}$ Thesis, School of Social Sciences, The University of Adelaide, Australia, 361 pp.

Carlton, S.J and Jacobson, S.K., 2013. Climate change and coastal environmental risk perceptions in Florida. Journal of Environmental Management, 130, 32-39.

Cazenave, A. and Le Cozannet, G., 2014. Sea level rise and its coastal impacts. Earth's Future, 2, 15-34.

Chaverot, S., Héquette, A. and Cohen, O., 2008. Changes in storminess and shoreline evolution along the northern coast of France during the second half of the $20^{\text {th }}$ century. Zeitschrift für Geomorphologie, Suppl.Bd. 52(3), 1-20.

Crapoulet, A., Héquette, A., Marin, D., Levoy, F. and Bretel, P., 2017. Variations in the response of the dune coast of Northern France to major storms as a function of available beach sediment volume. Earth Surface Processes and Landforms, 42(11), 1603-1622.

Douglas, E.M., Kirshen, P.H., Paolisso., M., Watson, C., Wiggin, J., Enrici, A. and Ruth, M., 2012. Coastal flooding, climate change as environmental justice: identifying obstacles and incentives for adaptation in two metropolitan Boston Massachusetts communities. Mitigation and Adaptation Strategies for Global Change, 17, 537-562.

Elrick-Barr, C.E., Smith, T.F., Thomsen, D.C. and Preston, B.L., 2015. Perceptions of risk among households in two Australian coastal communities. Geographical Research, 53(2), 145-159.
IPCC, 2013. Climate change 2013: The Physical Science Basis. Contribution of Working Group I to the Fifth Assessment Report of the Intergovernmental Panel on Climate Change, T.F. Stocker et al. (eds.), Cambridge University Press, Cambridge, 1535 pp.

Jongman, B., Ward, P.J. and Aerts, J.C.J.H., 2012. Global exposure to river and coastal flooding: long term trends and changes. Global Environmental Change, 22, 823-835.

Kellens, W., Zaalberg, R., Neutens, T., Vanneuville, W. and De Maeyer, P., 2011. An analysis of the public perception of flood risk on the belgian coast. Risk Analysis, 31(7), 10551068.

Lechowska, E., 2018. What determines flood risk perception? A review of factors of flood risk perception and relations between its basic elements. Natural Hazards, 94(3), 13411366.

Leiserowitz, A., 2006. Climate change risk perception and policy preferences: the role of affect, imagery, and values. Climatic Change, 77, 45-72.

Michel-Guillou, E. and Meur-Férec, C., 2017. Representations of coastal risk (erosion and marine flooding) among inhabitants of at-risk municipalities. Journal of Risk Research 20(6), 776-799.

Mills, M., Mutafoglu, K., Vanessa, M.A., Archibald, C., Bell, J. and Leon, J.X., 2016. Perceived and projected flood risk and adaptation in coastal Southeast Queensland, Australia. Climatic Change, 136, 523-537.

Mölter, T., Schindler, D., Albrecht, A. and Kohnle, U., 2016. Review on the projections of future storminess over the North Atlantic European region. Atmosphere, 7(4), doi.org/10.3390/atmos7040060.

Neumann, B., Vafeidis, A.T., Zimmermann, J. and Nicholls, R.J., 2015. Future coastal population growth and exposure to sea-level rise and coastal flooding - A global assessment. PLOS ONE 10(3): e0118571.

Ngo, C.C., Poortvliet, P. M. and Feindt, P.H., 2019. Drivers of flood and climate change risk perceptions and intention to adapt: an explorative survey in coastal and delta Vietnam, Journal of Risk Research, DOI: 10.1080/13669877.2019.1591484

O’Neill, E., Brereton, F., Shahumyan, H. and Clinch, J.P., 2016. The impact of perceived flood exposure on flood-risk perception: the role of distance. Risk Analysis, 36(11), 2158-2186.

Révillon, R., 2018. L'évaluation des représentations des habitants face aux risques côtiers à Oye-Plage et Wissant. Masters Dissertation, Université Littoral Côte d'Opale, Dunkirk, 91 pp.

Spence, A., Poortinga, W., Butler C. and Pidgeon N. F., 2011. Perceptions of climate change and willingness to save energy related to flood experience. Nature Climate Change, 1 (1): 46-49. 